九州大学学術情報リポジトリ

Kyushu University Institutional Repository

\title{
Climatic Variability and Impacts on Biodiversity at Local Level : A case Study from Kanchanjanga Conservation Area, Nepal
}

Devkota, Bimala Devi

Nepal Academy of Science and Technology (NAST)

Paudel, Prem Prasad

Department of Soil Conservation and Watershed Management

Bhuju, Dinesh Raj

Nepal Academy of Science and Technology (NAST)

Kubota, Tetsuya

Faculty of Agriculture, Kyushu University

https://doi.org/10.5109/25205

出版情報: 九州大学大学院農学研究院紀要. 57 (2)，pp.453-459，2012-09-20. Faculty of Agriculture, Kyushu University

バージョン：

権利関係 : 


\title{
Climatic Variability and Impacts on Biodiversity at Local Level: A case Study from Kanchanjanga Conservation Area, Nepal
}

\author{
Bimala Devi DEVKOTA ${ }^{1}$, Prem Prasad PAUDEL ${ }^{2}$, \\ Dinesh Raj BHUJU' ${ }^{1}$ and Tetsuya KUBOTA*
}

\author{
Laboratory of Erosion Control Division of Forest Environment Sciences, Department of \\ Agro-environmental Sciences, Faculty of Agriculture, Kyushu University, \\ Fukuoka 812-8581, Japan \\ (Received April 18, 2012 and accepted May 10, 2012)
}

\begin{abstract}
Impacts of climatic variability on biodiversity and livelihood aspects were examined in Kanchanjunga Conservation Area (KCA) Nepal .The area is characterized with unique gene pool, cultural, archeological, and historic values. Field reconnaissance survey, interaction with local communities and institutions were carried out for obtaining the necessary information. Linear trend analysis of climatic data in specific temperature and rainfall were analyzed for past 20 years. Major findings of the study were

1) Retreating of glacial lakes were evident, which may bring glacial lake outburst and flood; although no major river flow system was affected,

2) Blankets of snow/ice sheets were reported melted,

3) Habitat of snow leopard was affected and population balance between snow leopard and blue sheep was disturbed,

4) Forest and agro biodiversity, agriculture productivity were affected adversely due to unusual rainfall pattern, pests and diseases,

5) No major river flow system was affected. It was observed that interagency coordination for awareness generation, planning and implementation of climate change coping strategies specially focusing for biodiversity conservation felt urgent. Similarly it is suggested that trans-boundary issues are needed to be considered to address the issues of animal migration.
\end{abstract}

Keywords: biodiversity, climate change, KCA, climatic variability, trend analysis

\section{INTRODUCTION}

The global climate system is a consequence of and link between the atmosphere, the oceans, the ice sheets, living organisms, soils, sediments, rocks and changes continuously over a timescale. However, the climate in certain location varies between more or less extreme states and events called the climate variability, such as severe droughts, heavy rainfall, or unusually hot or cold weather.

Recently, the occurrence of extreme weather or climatic events has been used to indicate overall climate change.

Over the past few decades, human activity has significantly altered the atmospheric composition, leading to climate change of an unprecedented character. The average surface temperature of the earth has increased between $0.3^{\circ} \mathrm{C}$ and $0.6^{\circ} \mathrm{C}$ over the past hundred years and the increase in global temperature is predicted to increase between $3.5^{\circ}$ Celsius (C) and $5.5^{\circ} \mathrm{C}$ by 2100 for the Indian sub continent (IPCC, 2001a) and even greater increase is predicted for the Tibetan Plateau (Lal, 2002). Annual warming in the Himalayan region between 19771994 was $0.06^{\circ} \mathrm{C}$ (Shrestha et al., 1999). As per the third assessment report of the IPCC, the spatial average annual mean warming over the Asian region is projected to be as much as by $3^{\circ} \mathrm{C}$ by 2050 and about $5^{\circ} \mathrm{C}$ by the

\footnotetext{
Nepal Academy of Science and Technology (NAST)

Department of Soil Conservation and Watershed Management, Nepal

* Corresponding author (E-mail: kubot@agr.kyushu-u.ac.jp)
}

2080s as a result of continued green house gas emission. Multiple consequences globally or locally are experiencing around the globe. For instance, a $1^{\circ} \mathrm{C}$ rise in temperature will cause alpine glaciers worldwide to shrink as much as $40 \%$ in area and more than $50 \%$ in volume as compared to 1850 (IPCC, 2001b). Food and Agriculture Organization (FAO) has also estimated that climate change and its implications can reduce crop yields up to $30 \%$ in the South Asian region.

Located in the eastern Himalayan region, Kanchanjunga Conservation Area (KCA) is an extraordinarily high mountain chain, encompassing many varied cultures and an extensive diversity of flora and fauna (Table 1). This study was carried out to know the climate change impacts mainly on freshwater, biodiversity, vegetation and livelihood.

Table 1. Biodiversity status in KCA

\begin{tabular}{llrl}
\hline SN & Particulars & $\begin{array}{r}\text { Species } \\
\text { Number }\end{array}$ & Remarks \\
\hline 1 & Angiosperms & 835 & \\
2 & Gymnosperms & 9 & \\
3 & Birds & 253 & Wood snipe is in endangered stage \\
4 & Mammals & 58 & Musk Deer, Red Panda are in \\
5 & Flowering plants & 2000 & \\
6 & Orchids & 48 & \\
\hline
\end{tabular}

(Source: Carpenter, 1996) 


\section{MATERIALS AND STUDY METHODS}

\section{Salient features of the study area}

Kanchanjunga Conservation Area, covering an area of $2,035 \mathrm{~km}^{2}$ is located in Taplejung district, the north eastern part of Nepal, bordering India's Sikkim to the east and Tibet Autonomous Region of China to the north (Figure 1). The KCA covers more than $56 \%$ of the total district area. KCA region includes Mt. Kanchanjunga $(8,586 \mathrm{~m})$, the third highest mountain in the world and it is also home to 14 mountain peaks over $7,000 \mathrm{~m}$ and one of the longest glaciers on the earth. In support of World Wildlife Fund (WWF)'s Living Planet Campaign, then His Majesty's Government of Nepal (HMG/N) declared Kanchanjunga area as a "Gift to the earth" in April 1997, followed by conferring it a full-protected area status and declaring it a conservation area in July 1997. KCA is the only protected area of Nepal managed by local communities. The KCA region falls within WWF's "Global 200 Eco regions" and eco-region based conservation of eastern Himalaya.

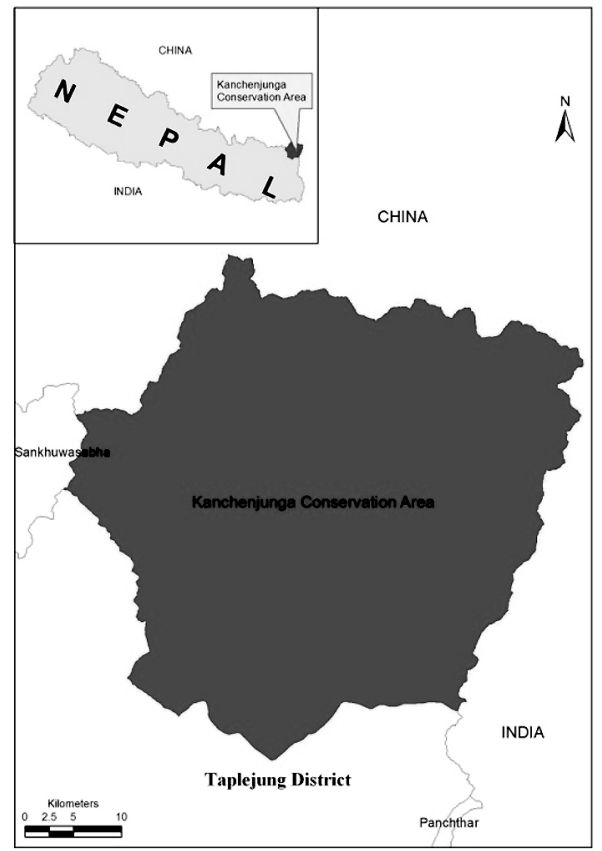

Fig. 1. Location map of the study area, Kanchanjunga Conservation Area (KCA).

\section{Topography}

The altitude of the KCA region varies from 1,200 m asl (Thiwa Khola) to $8586 \mathrm{~m}$ asl (Mt. Kanchanjunga). Below 4,000 m, topography is characterized with narrow V-shaped valleys with steep side slopes. The three main rivers (Tamur, Ghunsa, and Shimbuwa) and their tributaries drain the area. These rivers cut deeply into the mountains, creating deep gorges. The different valleys are distinct from one another in that they possess varied forest types and floristic elements. Existing glaciers extend over an area of $400 \mathrm{~km}^{2}$ and altitude range of almost $5,000 \mathrm{~m}$. About $65 \%$ of the area is covered by rock and ice, $14.1 \%$ by forests, $10.1 \%$ by shrubland, $9.2 \%$ by grassland, and $1.6 \%$ by agricultural land.

\section{Flora, Fauna and Bioclimatic zones}

The specific climatic conditions in combination with varied topographic nature in KCA give rise to diverse ecological habitat of very rich flora and fauna. There are some rare and endangered species eg. Uncia uncia (Snow leopard), Ursus thibetanus (Himalayan black bear), Moschus chrysogaster (Musk deer), Ailurus fulgens (Red Panda), Canis lupus (Grey wolf). Other important mammlas of this area includes Common leopard (Panthera pardus), Blue sheep (Pseudois nayaur), and Common langur (Semnopithecus entellus). The region reportedly hosts 2,000 species of flowering plants, 48 types of orchids, 137 types of non timber forest products, 253 species of birds, 58 species of mammals, extensive Himalayan larch forest (Larix griffithiana), Juniper forest (Juniperus indica), at least 252 species of migrant and resident birds, eight of which are considered to be at risk in Nepal (Carpenter, 1996).

Along the landscapes four bio-climatic zones comprise distinct vegetation belts (Dobremez and Shakya, 1975; Shrestha, 1994; Shrestha and Ghimire, 1996), viz.

a) Subtropical bioclimatic belt (1,000-2,000 m),

b) Temperate bioclimatic belt (2,000-3,000 m),

c) Subalpine bioclimatic belt (3,000-4,000 m), and

d) Alpine bioclimatic belt $(>4,000 \mathrm{~m})$.

\section{Socio-economic conditions}

The agriculture, forest and livestock rearing are closely linked to the livelihood of the local communities. The area accommodates about 1,050 households with culturally diverse ethnic groups including Sherpa, Limbu, Rai, Gurung, Tamang, Sarki, Damai, Kami, Brahamin, Samal and Tibetan refugees. In lower altitude, communities of mixed ethnicity practice a mixture of shifting cultivation, harvesting of forest products. The higher altitude settlements are agro pastoral and, due to the short growing season, the rearing of Yaks and their hybrids predominates. In these higher regions, the seasonal movement of livestock between mountain and lowland pastures is evolved as an adaptation to the alpine environment. In the lower altitude communities, the cardamom as a cash crop is becoming one of the most important income generating activities.

\section{STUDY METHODS}

Multidisciplinary team members comprising experts on agriculture, forestry, flood/erosion hazards, social, and hydrology have examined the impacts of climate change on various aspects. Field reconnaissance survey was carried out in March and April 2009 along the route (Fig. 2), target group discussions were done with the local community groups along the route. Intensive review of secondary information was done to understand the state of climate change impacts along Himalayan arc.

\section{Statistical analysis of the climatic data}

In order to understand the climatic variability, monthly minimum, monthly maximum temperature records were obtained from the Taplejung Station located 


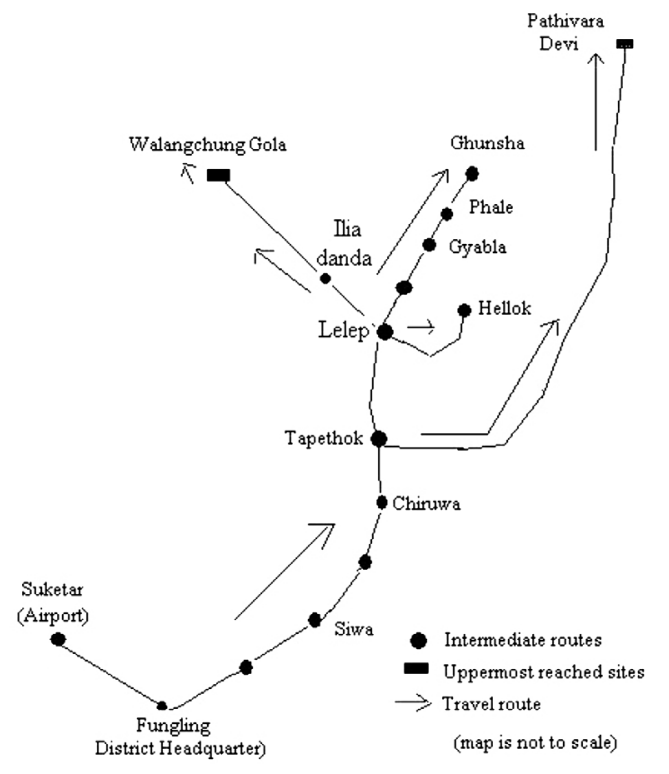

Fig. 2. Routes of the field survey.

at $1,732 \mathrm{~m}$ asl and monthly rainfall records were examined for 20 years (1988-2007). The local people reported that they were observing the changing scenario since past 15-20 years.

Simple statistical analysis such as mean, range, standard deviation, and coefficient of variation, are calculated. Based on the time series records of temperature available for 20 years (1988-2007), linear trend line equations are computed by using the following relationships;

$$
Y=a+b x
$$

Thus, for a given time $t$, the estimated value $Y_{e}$, of $Y$ (temperature axis) can be written as;

$$
Y_{e}=a+b x
$$

The value of $a$ and $b$ was computed by using the following equations (3) and (4), respectively;

$$
\begin{aligned}
& \sum Y=n a+b \sum x \\
& \sum x y=a \sum x+b \sum x^{2} \\
& \text { and, } x=2(t-1997.5)
\end{aligned}
$$

Where, the number of data $n$ is 20 (Climatic data series of 20 years), year 1997.5 is middle year of the data series, and $t$ is the corresponding time.

\section{RESULTS}

\section{Snow/Ice and Glaciers}

In the uppermost part of KCA region (mainly above $3,000 \mathrm{~m}$ ) a substantial proportion of the annual precipitation falls as snow. In the higher ridges, snowfall builds up as ice sheets from year to year to form glaciers that provide long term reservoirs of water which has supported the life of various flora and fauna. In case the Thanjen glacier bursts, many communities will be affected because of their location close to Ghunsa village. The length and breadth of the Aemtachhi glaciers has increased compared to10-15 years back.

\section{Climatic variability}

In order to know the climatic conditions (temperature and rainfall) in the study area trends were examined for 20 years (1988-2007) and results are shown below in Figures 3, 4, 5a and 5b.

The above figures reveals that both monthly maxi-

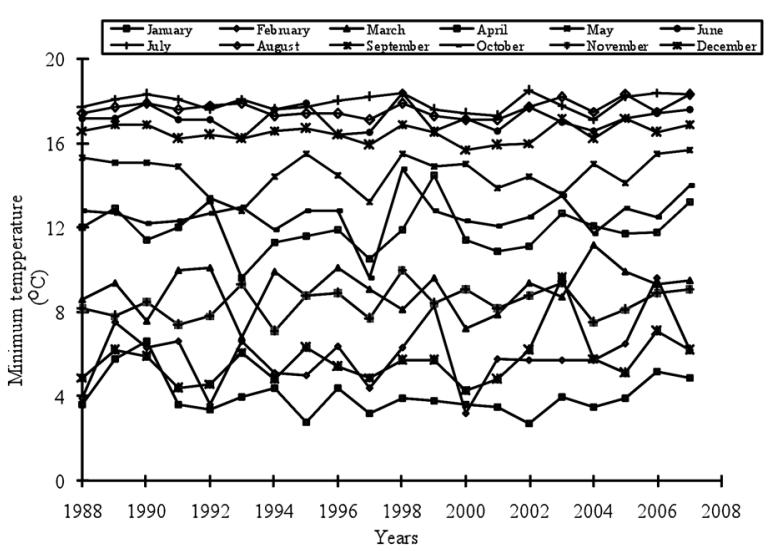

Fig. 3. Average monthly minimum temperature pattern in KCA region, Nepal (1988-2007).

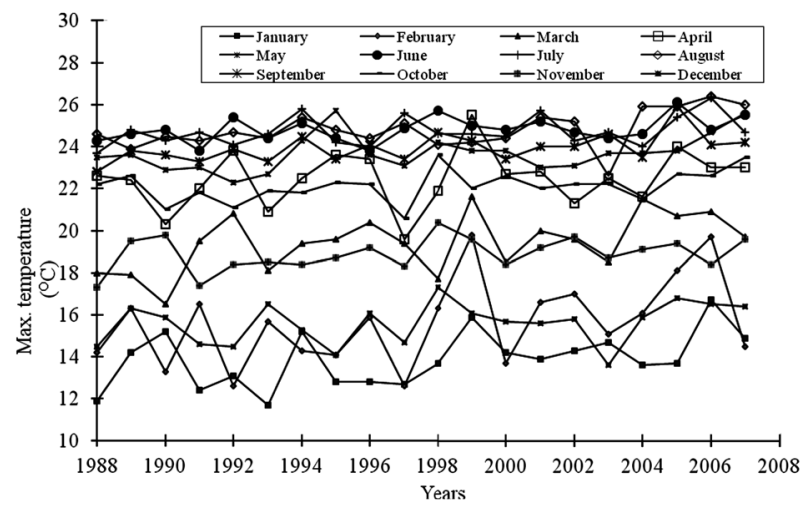

Fig. 4. Average monthly maximum temperature pattern in KCA region, Nepal (1988-2007).

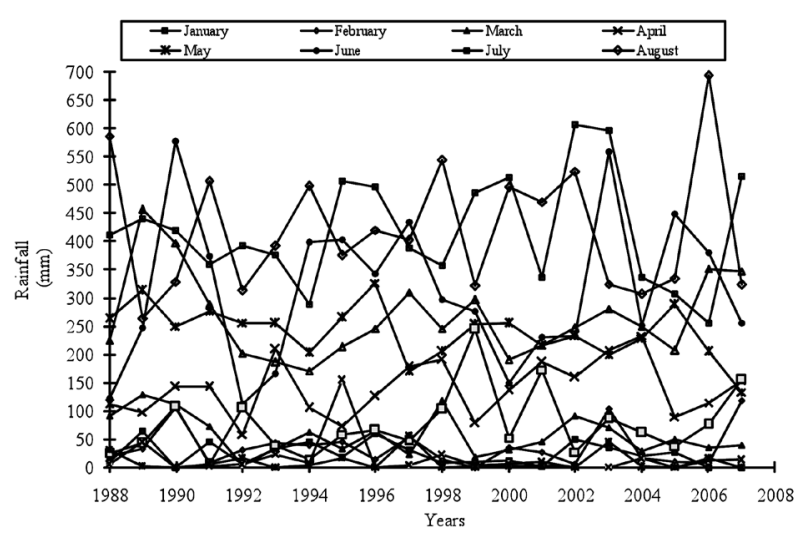

Fig. 5a. Average monthly rainfall pattern in KCA region, Nepal (1988-2007). 


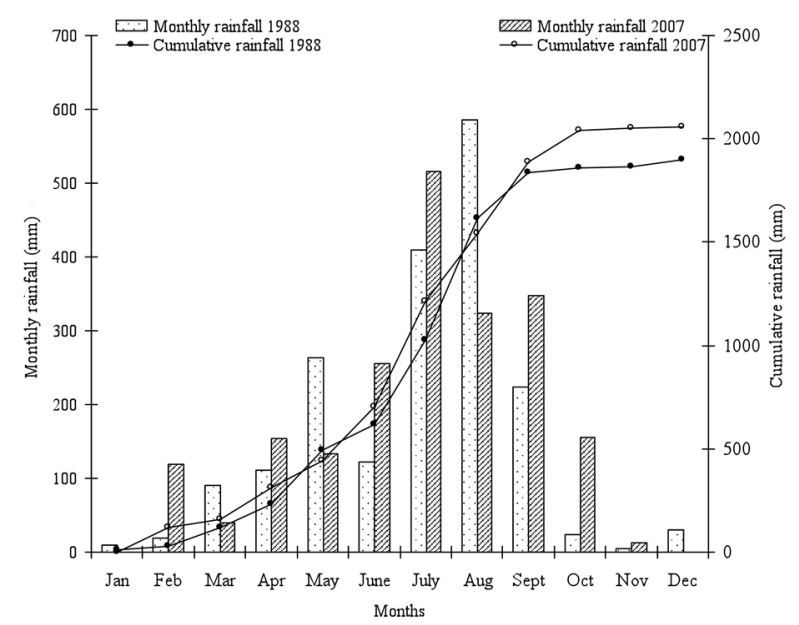

Fig. 5b. Comparison of monthly rainfall (left axis) and cumulative pattern (right axis) between 1988 and 2007.

mum and monthly minimum temperature records are higher in the year 2007 compared to the 20 years before i.e. in the year 1988. For instance, the monthly maximum temperature, for the January 1988 was $11.9^{\circ} \mathrm{C}$, while it increased to $14.9^{\circ} \mathrm{C}$ for the January 2007. Similarly, for monthly minimum for the January, it was $3.6^{\circ} \mathrm{C}$ and $4.9^{\circ} \mathrm{C}$, for the years 1988 and 2007, respectively. We conclude that since past 20 years (1988-2007) the monthly maximum and monthly minimum temperature are in rising trends for the all months (Figs. 3-5).

Comparison of the rainfall patterns between 1988 and 2007 (Fig. 5) indicated that cumulative rainfall pattern was slightly higher in 2007 (1,896.9 mm and 2,055 mm, for 1988 and 2007, respectively) and annual rainfall amount was fluctuating in every 2-3 years. According to the local officials and communities, there was no rainfall in the year 2008 monsoon season and the temperature was also rising (feeling hot).

\section{Forest conditions}

There was massive forest fire in the $\mathrm{KCAu}$ region in 2008. It was revealed that about 300 hac. of forest area was affected across Yamphuden, Illahadanda, Amilesha, Lelep, Hellok, which damaged the pasture land, Nigalo (Drepanostachyum sps.), and also Pinus plantation area. Decreasing population of Michalia champaca, excessive growth of Alnus nepalensis may cause threat to biodiversity loss.

The damaging scale of forest fire was in larger extent, and could be due to dryness and warmth environmental conditions. Impacts were observed on biodiversity, and habitats due to the forest fire. The area is also rich in medicinal plants and non-timber forest products. Major species of such includes Chiraito (Swertia sps.), Kutki (Picrorhiza scrophurariflora), Jatamashi (Valeriana jatamasi), Nirmashi (Parnassia nubikola)(also known as Bishma), Sunpati (Rhododendron anthopogan), Thulo okhati, Bish (Aconitum sps), Micopila (mainly in Gola), Lokta (Daphne bholua) and Argeli (Daphne sureil) (used in local paper preparation), Lout Sallo (Taxus baccata- used in cancer control medicine), and
Hattighar. These species are very useful for the local communities and their population is also increasing gradually. The species Chanp (Michalia champaca) is using extensively, so its population is in decreasing trend. Uttis (Alnus nepalensis), Malingo (Thamnocalamus spathiflorus), and Cardamom (Amomum aromaticum) are increasing vigorously. Uttis is the pioneer species of eroded land and can be grown easily in diverse condition. Cardamom is becoming very popular for cash income which the local communities are cultivating extensively and Swertia species is also becoming popular as cash crops.

\section{Biodiversity and impacts of climate change}

Kanchanjunga mountain region hosts a series of climatically different zones over short distances and elevations supporting different microhabitats and niches. The early arrival and the late departure of the monsoon cause a prolonged wet season and very humid summer conditions. These specific climatic conditions in combination with varied topographic nature give rise to rich flora and fauna. For instance, out of total 36 species of Rhododendron, 24 species are available in the KCA region alone. As there was reporting of early flowering, the color and sizes of Rhododendron flowers, we presume they have been affected by recent climatic variability.

According to local respondents, the population of blue sheep, red panda, and snow leopards was increasing as they appeared more frequently along the trekking routes. However, balancing the population between snow leopard and blue sheep is becoming challenging. The melting of the snow and no snowfall events have both beneficial and adverse effects for the Snow leopards' habitat because in one hand, snowmelt can open new grassland areas (supportive), and reduced snow blanket can cause unfavorable situation for their habitat (disturbance). The local communities also said that the population of Dhedu monkey was in declining trend, because they rarely observed the wild animals as compared to few years ago. The reasons why their population decreased, and factors disturbing their habitats are not clearly known.

The detail consequences felt by the local people due to climate change is summarized in Table 2.

\section{Climatic variability}

Salient features

In the study site of KCA June-August were the warmest months (monthly maximum temperature range $24.73-24.81^{\circ} \mathrm{C}$, while January is the coldest one (maximum $13.8^{\circ} \mathrm{C}$ ). While higher fluctuations in temperature (maximum 12.6 to $19.8^{\circ} \mathrm{C}$ ), and minimum $\left(3.2\right.$ to $9.6^{\circ} \mathrm{C}$ ) were observed in February and less variation in June/ July. The fluctuation in the temperature supports for frequency and magnitude of extreme weather events, which ultimately supports for global warming. To know the trend analysis of the time series temperature pattern, linear trend analysis is computed by using the $Y=a+b x$ relationship and the obtained results are summarized in Table 3. 
Climate change evidences, vulnerable entities

From Figs. 3 and 4 and Table 3 it can be concluded that the temperature is in increasing trend and the rainfall pattern is also fluctuating. These climatic changes are influencing on ecosystem's (aquatic and terrestrial) leading to vulnerability. Although frequent occurrence of slope failures and GLOF events were not observed, some landslides have occurred sporadically in some locations.

Table 2. Response on effects of increased temperature on plants and animals

\begin{tabular}{|c|c|c|}
\hline Species, Type / Events & Responses & Remarks \\
\hline $\begin{array}{l}\text { Domestic animals } \\
\text { (cattle) }\end{array}$ & $\begin{array}{l}\text { - Itching, water bodies } \\
\text { appearances in body parts }\end{array}$ & $\begin{array}{l}\text { - Water bodies disappear suddenly, may be due to excessive hot (according } \\
\text { to local respondent). }\end{array}$ \\
\hline Alainchi & $\begin{array}{l}\text { - No uniform maturity since } \\
\text { last two years }\end{array}$ & - Major income source, dominates other herbs and shrubs plants. \\
\hline Orange & - Early flowering & - Warmer weather condition. \\
\hline $\begin{array}{l}\text { Deciduous fruits } \\
\text { (Apples, Aru, } \\
\text { Alupokhada) }\end{array}$ & - Late flowering & - Seedling distribution and plantation of Apples started since past 5 years. \\
\hline Chanp and Gurans & - Early flowering & \\
\hline Lokta and Argeli & - Low natural growth & - Started seedling production in nursery and plantation in wide areas. \\
\hline Trees trunk & - Started dying & $\begin{array}{l}\text { - Might be due to decreases in soil moisture, available water in root zone } \\
\text { especially in soil-rocky terrain. }\end{array}$ \\
\hline Fire proneness & - Increased & - Due to warmth and increased dryness. \\
\hline Snow fall & $\begin{array}{l}\text { - Nil in the winter since last } \\
\text { year. }\end{array}$ & - Scenic beauty of mountain decreased, due to no blanketing. \\
\hline $\begin{array}{l}\text { Life cycle of crops/ } \\
\text { Food security }\end{array}$ & - Deviated & $\begin{array}{l}\text { - Life cycle Cardamom was affected, (no uniform maturity), low } \\
\text { production, and appearance of rhizome rot). } \\
\text { - The dryness has hampered wheat production. The growth of wheat plant } \\
\text { was stunted, with fewer tillers. } \\
\text { - Decreased water availability in the root zone has affect fruiting/flowering } \\
\text { of the agricultural crops. } \\
\text { - Maize cultivation was affected due to drought, Taplejung district is } \\
\text { already food deficit area, hence further decrease on agricultural } \\
\text { production and cash crops may create acute problem to the life. } \\
\text { - No rainfall in regular time/normal time. }\end{array}$ \\
\hline
\end{tabular}

Table 3. Computation of the linear trend equations

\begin{tabular}{|c|c|c|c|c|}
\hline Month & Temperature & Value of a & Value of $b$ & $\begin{array}{l}\text { Trend equation } \\
\qquad\left(Y_{e}=a+b x\right)\end{array}$ \\
\hline January & $\begin{array}{l}\text { Maximum } \\
\text { Minimum }\end{array}$ & $\begin{array}{r}13.88 \\
4.04 \\
\end{array}$ & $\begin{array}{r}0.053 \\
-0.013 \\
\end{array}$ & $\begin{array}{l}Y_{e}=13.88+0.053 x \\
Y_{e}=4.04-0.013 x\end{array}$ \\
\hline February & $\begin{array}{l}\text { Maximum } \\
\text { Minimum }\end{array}$ & $\begin{array}{r}15.62 \\
5.92 \\
\end{array}$ & $\begin{array}{l}0.074 \\
0.033\end{array}$ & $\begin{array}{l}Y_{e}=15.62+0.074 x \\
Y_{e}=5.92+0.033 x\end{array}$ \\
\hline March & $\begin{array}{l}\text { Maximum } \\
\text { Minimum }\end{array}$ & $\begin{array}{r}19.16 \\
9.06 \\
\end{array}$ & $\begin{array}{r}0.06 \\
0.018 \\
\end{array}$ & $\begin{array}{l}Y_{e}=19.16+0.06 x \\
Y_{e}=9.06+0.018 x\end{array}$ \\
\hline April & $\begin{array}{l}\text { Maximum } \\
\text { Minimum }\end{array}$ & $\begin{array}{l}22.47 \\
11.89\end{array}$ & $\begin{array}{l}0.023 \\
0.008\end{array}$ & $\begin{array}{l}Y_{e}=22.47+0.023 x \\
Y_{e}=11.89+0.008 x\end{array}$ \\
\hline May & $\begin{array}{l}\text { Maximum } \\
\text { Minimum }\end{array}$ & $\begin{array}{l}23.70 \\
14.59\end{array}$ & $\begin{array}{l}0.031 \\
0.005\end{array}$ & $\begin{array}{l}Y_{e}=23.70+0.031 x \\
Y_{e}=14.59+0.005 x\end{array}$ \\
\hline June & $\begin{array}{l}\text { Maximum } \\
\text { Minimum }\end{array}$ & $\begin{array}{l}24.81 \\
17.17 \\
\end{array}$ & $\begin{array}{r}0.02 \\
0.0006 \\
\end{array}$ & $\begin{array}{l}Y_{e}=24.81+0.02 x \\
Y_{e}=17.17+0.0006 x\end{array}$ \\
\hline July & $\begin{array}{l}\text { Maximum } \\
\text { Minimum }\end{array}$ & $\begin{array}{l}24.73 \\
17.92\end{array}$ & $\begin{array}{l}0.021 \\
0.001\end{array}$ & $\begin{array}{l}Y_{e}=24.73+0.021 x \\
Y_{e}=17.92+0.001 x\end{array}$ \\
\hline August & $\begin{array}{l}\text { Maximum } \\
\text { Minimum }\end{array}$ & $\begin{array}{l}24.81 \\
17.62 \\
\end{array}$ & $\begin{array}{l}0.034 \\
0.006 \\
\end{array}$ & $\begin{array}{l}Y_{e}=24.81+0.034 x \\
Y_{e}=17.62+0.006 x\end{array}$ \\
\hline September & $\begin{array}{l}\text { Maximum } \\
\text { Minimum }\end{array}$ & $\begin{array}{l}23.94 \\
16.49\end{array}$ & $\begin{array}{r}0.03 \\
0.0006\end{array}$ & $\begin{array}{l}Y_{e}=23.94+0.03 x \\
Y_{e}=16.49+0.0006 x\end{array}$ \\
\hline October & $\begin{array}{l}\text { Maximum } \\
\text { Minimum }\end{array}$ & $\begin{array}{l}22.12 \\
12.59\end{array}$ & $\begin{array}{r}0.02 \\
0.011\end{array}$ & $\begin{array}{l}Y_{e}=22.12+0.02 x \\
Y_{e}=12.59+0.011 x\end{array}$ \\
\hline November & $\begin{array}{l}\text { Maximum } \\
\text { Minimum }\end{array}$ & $\begin{array}{l}18.9 \\
8.45\end{array}$ & $\begin{array}{l}0.02 \\
0.02\end{array}$ & $\begin{array}{l}Y_{e}=18.9+0.02 x \\
Y_{e}=8.45+0.02 x\end{array}$ \\
\hline December & $\begin{array}{l}\text { Maximum } \\
\text { Minimum }\end{array}$ & $\begin{array}{r}15.61 \\
5.7\end{array}$ & $\begin{array}{r}0.02 \\
0.035\end{array}$ & $\begin{array}{l}Y_{e}=15.61+0.02 x \\
Y_{e}=5.7+0.035 x\end{array}$ \\
\hline
\end{tabular}

$Y_{e}=$ expected value of temperature, $x=2$ ( $\left.t-1997.5\right), x$ axis denotes for different time (years). 
Table 4. Overview of climate change evidences, vulnerable elements

\begin{tabular}{|c|c|c|}
\hline Parameter & Impacts/evidences & Vulnerable entities/elements \\
\hline $\begin{array}{l}\text { Snow/ } \\
\text { Glaciers }\end{array}$ & $\begin{array}{l}\text { Melting snow cover due to temperature rise. } \\
\text { No snow fall since past two years. }\end{array}$ & $\begin{array}{l}\text { Janu south, Yalung, Thanjen, Aemtachhi glaciers, } \\
\text { adjoining areas of Dudh Pokhari, Yamphudin, and } \\
\text { Ghunsa, respectively. } \\
\text { Lowering albedo prone to radiative melting. }\end{array}$ \\
\hline Freshwater & $\begin{array}{l}\text { Disappearance of few water sources, } \\
\text { Historic evidences of lake burst eg. Nangma, Chherching, } \\
\text { Availability/supply of water, in river basins/tributaries are } \\
\text { sometimes increasing. }\end{array}$ & $\begin{array}{l}\text { Water availability in major rivers (eg. Tamor } \\
\text { River, Ghunsa Khola, Gola), Nangma, Cherching, } \\
\text { Tamor, Shirpokhari lakes. } \\
\text { River pollution, hygienic problems. }\end{array}$ \\
\hline Bio-diversity & $\begin{array}{l}\text { Population of Blue sheep, Red Panda, and Snow leopards } \\
\text { are increasing. } \\
\text { Early flowering of Rhododendron, and appearance of } \\
\text { fruits. } \\
\text { Started dying back of tree trunk, showing signs of frag- } \\
\text { mentation and degradation, climate warming can increase } \\
\text { suitable habitats for the water weeds. }\end{array}$ & $\begin{array}{l}\text { Rhododendron species (c.f. the KCA hosts } 24 \\
\text { species of Rhododendron out of total } 36 \text { species), } \\
\text { agro-ecosystem pattern. }\end{array}$ \\
\hline Agriculture & $\begin{array}{l}\text { No uniform maturity in Alainchi. } \\
\text { Itching/waterbodies appearing in cattle. } \\
\text { Early flowering in orange. } \\
\text { Low natural growth in Lokta and Argeli. } \\
\text { Late flowering in Apples, Aru, Alupokhada. } \\
\text { Appearance of some diseases and pests. } \\
\text { Stunted growth of wheat with less tillers. } \\
\text { Affecting maize cultivation due to drought. }\end{array}$ & $\begin{array}{l}\text { Alainchi, cattles, Lokta, deciduous fruits, maize, } \\
\text { apples, and other cash crops. }\end{array}$ \\
\hline
\end{tabular}

Glaciers burst, snow fall decreasing, melting of snow blankets, soil quality deterioration/land degradation due to excessive grazing, and life cycle change of some species (e.g. early fruiting, flowering), and appearance of some diseases in plant, animal are some of the impacts of climate change experienced by the local communities, and are summarized in Table 4.

\section{DISCUSSION}

The mountain landscape is one the most dynamic and complex ranges in the world due to tectonic activity, and they are vulnerable to global warming and increasing human activities (Bandyopadhyay and Gyawali, 1994). Uncertainties about the rate and magnitude of climate change and potential impacts prevail, but the above mentioned facts revealed that it is gradually and powerfully changing the ecological and socioeconomic status of the Kanchanjunga region.

The present study aimed to investigate the vulnerability states of community resources based on empirical evidences from field observation and interview with local people. For the study area, the time series data and other systematic climate change related data were not sufficiently available. As the KCA people have long experience on past unusual events (Glacial lake outburst, drought, etc.), hence, participatory vulnerability analysis has provided sufficient climate change related evidences. The past study evidences have shown ecological response due to climate change like advances in timing of spring events (change in bird species, excessive invasive plant species) and appearances of epidemic disease (Walther et al., 2002). In the study area too, there was similar observation about the appearance of new water bodies. The study carried out in Churiya region (Paudel, 2011) has also suggested about the change in floral feature (leaf color change) in recent years. Communities have adapted themselves and developed resiliency to face some extreme unusual events. It means they have wealth of experience on how to deal with some extreme events. But some additional techniques, suggestions from external institutions will encourage the local communities to cope with unusual events. This study revealed some insights on the vulnerability state and impacts of climate change, which are as follows.

1) The temperature was deviated positively during the course of 20 years (1988-2007), while the annual cumulative rainfall during was fluctuated in every 2-3 years interval.

2) Glaciers were among the most sensitive indicators of climate change, advancing substantially during climate cooling and retreating during climate warming. Glaciers grow and collapse, both contributing to natural variability and greatly amplifying externally forced changes eg. Nagma, Tamor Shirpokhari.

3) Decreasing snow fall, and melting of blankets of snow/ice sheets affecting mountain albedo and habitat of Snow leopard. Upto now there is no change in major river flow system, however; after few years if the climatic situation remains unusual, freshwater system/hydrological system may also affected.

4) Population balance between Snow leopard and Blue sheep is becoming matter of serious consideration.

5) Forest biodiversity, agro biodiversity, agriculture productivity are being affected. For instance, early flowering, early maturity, appearances of some pests/ diseases (e.g. water bodies in cattle) are some evidences of climate change related consequences.

6) Forest fire was observed in the site. Hence, precautionary measures should be taken to minimize the 
fire damage. For this, awareness campaign, forest line constructions are suggested.

7) Interagency coordination for awareness generation, planning and implementation of climate change coping strategies are becoming essential and WWF is required to facilities for this process.

8) As KCA is characterized with its outstanding peculiar features, the National Adaptation Plan of Action (NAPA) should incorporate KCA for identification of hotspots, and develop plan of action and monitoring schemes.

9) Trans boundary issues should be taken into consideration to address the issues of migration, habitat management and other related consequences. In addition, this study is recommending some activities, projects to conserve the outstanding significance and consideration on such matters are essential.

\section{CONCLUSION}

In present context of ecosystem based adaptation, climate change related issues should be deal in the integrated and coordinated way through incorporating local, national, regional, global scenarios. The data base related with climate change and other associated impacts are very limited to conclude, however; there are some evidences about the climatic variability trends (e.g. minimum temperature increasing throughout the months) and such evidences should be measure periodically and causative effects should be monitored closely.

\section{ACKNOWLEDGEMENTS}

This study was supported by WWF Nepal. We express our sincere thanks to the local people of the KCA for their help during the study.

\section{REFERENCES}

Bandyopadhyay, J. and D. Gyawali 1994 Himalayan water resources Ecological and political aspects of management. Mountain Research and Development, 14(1): 1-24

Carpenter, C. C. 1996 Pattern of bird species richness in the Tamur River basin, Seasonal and elevation trends wildland studies, Report Sanfrancisco State University: 12-24

Dobremez, J. F. and P. R. Shakya 1975 Ecological Map of Nepal, 6: $33-48$

Intergovernmental Panel on Climate Change (IPCC) 2001a Climate Change 2001: The scientific basis, contribution of working group I to the third assessment report of IPCC on climate change. Cambridge University press, Cambridge (U.K.)

IPCC 2001b Impacts, Adaptation and vulnerability, contribution of working group II to the third assessment report of IPCC on climate change. Cambridge University press, Cambridge (U.K.)

Lal, M. 2002 Possible impacts of global climate change on water availability in India, report to global environment and energy in the $21^{\text {st }}$ century. New Delhi, Indian Institute of Technology: $5-25$

Paudel, P. P. 2011 Vulnerability analysis due to climate change in Churiya Region. Unpublished report

Shrestha, K. K. and S. K. Ghimire 1996 Plant diversity inventory of the proposed Kanchenjunga Conservation Area (Ghunsa and Simbua valley). WWF Nepal Program, Report series 22

Shrestha, K. K. 1994 Floristic diversity, vegetation and ethnobotany of the proposed Kanchenjunga Conservation Area. WWF Nepal Program, Report series 6

Shrestha, A. B., C. P. Wake, P. A. Mayeski and J. E. Dibb 1999 Maximum temperature trends in the Himalayan and its vicinity. An analysis based on temperature records from Nepal for the period 1971-94. Journal of Climate, 12: 2773-2787

Walther G. R., E. Post, P. Convey and A. Menzels 2002 Ecological responses to recent climate change. Macmillan Magazines Ltd, pp. 389-394 